KS. ZBIGNIEW JANCZEWSKI

Wydział Prawa Kanonicznego

Uniwersytetu Kardynała Stefana Wyszyńskiego w Warszawie

\title{
SAKRAMENTY W UCHWAŁACH II SYNODU ARCHIDIECEZJI KATOWICKIEJ
}

Treść: Wstęp. - 1. Chrzest i bierzmowanie. - 2. Eucharystia. - 3. Sakramenty uzdrowienia. - 4. Sakrament święceń. - 5. Małżeństwo. - Zakończenie.

\section{Wstęp}

W latach siedemdziesiątych XX wieku odbył się I Synod Diecezji Katowickiej. Był on wyrazem recepcji postanowień Soboru Watykańskiego II. Jako pierwszy z polskich synodów posoborowych w znacznej mierze uwzględnił nowe spojrzenie na współczesny Kościół, wypracowane przez Ojców Soborowych. Około czterdzieści lat później arcybiskup Wiktor Skworc powołał drugi w historii diecezji synod, pragnąc aby owoce jego obrad włączały aktualne charyzmaty i dary łaski, w postawie posłuszeństwa odnawiając gorliwość wobec otrzymanych obowiązków i zadań.

Dnia 20 marca 2012 r. metropolita katowicki na posiedzeniu Rady Kapłańskiej poinformował o woli zwołania synodu, prosząc równocześnie o opinię Rady w tej kwestii. Po trzyletnim okresie przygotowań, 14 marca 2015 r. Odbyła się I sesja plenarna. Ostatnia taka sesja, XII, miała miejsce 20 listopada 2016 r. W jej trakcie uroczyście zamknięto synod, prezentując dokument końcowy, w tym też dniu arcybiskup metropolita katowicki Wiktor Skworc promulgował uchwały synodalne ${ }^{1}$.

\footnotetext{
${ }^{1}$ Wsłuchani w Ducha. Uchwały II Synodu Archidiecezji Katowickiej, Katowice 2016, s. 9, 153-158.
} 
Przedmiotem zainteresowania niniejszej publikacji są postanowienia synodalne dotyczące sakramentów św. Normy poruszające te kwestie znalazły się w kilku miejscach dokumentu końcowego. Chrzest, bierzmowanie i Eucharystia są zasadniczo omawiane we fragmencie zatytułowanym „Duszpasterstwo sakramentów i sakramentaliów” w rozdziale III - „Liturgia (leiturgia) Kościoła katowickiego". Znajdują się tam również postanowienia dotyczące pokuty i namaszczenia chorych. Normy odnoszące się do pozostałych sakramentów umieszczono przede wszystkim w rozdziale I, zatytułowanym „Wspólnota (koinonia) Kościoła katowickiego” - święcenia w podpunkcie „Powołania i formacja do prezbiteratu w Kościele katowickim”, a małżeństwo w „Duszpasterstwo rodzin w Kościele katowickim”. Pojedyncze przepisy dotyczące sakramentów można również znaleźć w innych miejscach uchwał.

Poza Uchwałami II Synodu Archidiecezji Katowickiej ukazały się też liczne akty wykonawcze, zebrane w organie urzędowym archidiecezji katowickiej - Wiadomościach Archidiecezjalnych, Suplement 2016. Wśród nich także niektóre odnoszą się do prawa o sakramentach, na przykład: „Dekret o udzieleniu spowiednikom władzy delegowanej do rozgrzeszania cenzur wiążących mocą samego prawa”, „Wskazania dotyczące przygotowania do sakramentów wtajemniczenia chrześcijańskiego w archidiecezji katowickiej”, „Wskazania dotyczące zmian we wpisach do ksiąg parafialnych" i inne. Dokumenty te jednak wymagają omówienia w oddzielnej publikacji. Niniejszy artykuł dotyczy więc jedynie samych uchwał synodalnych.

\section{Chrzest i bierzmowanie}

Kodeks prawa kanonicznego nakłada na duszpasterzy i pozostałych wiernych obowiązek troski o to, aby proszący o sakramenty zostali przygotowani do ich przyjęcia, poprzez ewangelizację i katechezę. Należy przy tym uwzględnić normy wydane przez odpowiednią wła$\mathrm{dzę}^{2}$. Normy takie znalazły się w Uchwałach II Synodu Archidiecezji Katowickiej. Jedna z nich zawiera zarządzenie, prowadzenia w każdej

\footnotetext{
${ }^{2}$ Kan. 843 par. 2.
} 
parafii specjalnej katechezy dla rodziców dzieci, przygotowujących się do sakramentów inicjacji chrześcijańskiej. Spotkania takie mają wpisywać się w całokształt duszpasterstwa katechetycznego, a nie tylko w zakres działań pedagogizujących, czy organizacyjnych. Materiały pomocnicze do prowadzenia katechez, opracowane zostaną przez Wydział Duszpasterstwa Rodzin ${ }^{3}$. Zatem w parafiach archidiecezji należy prowadzić specjalne katechezy dla rodziców dzieci, mających przystąpić do sakramentu chrztu, bierzmowania i Eucharystii. Spotkania z rodzicami są praktykowane od dawna, jednakże teraz zamiast formy przekazywania informacji organizacyjnych czy wychowawczych, powinny przyjąć one strukturę katechezy dorosłych.

Aby chrzest mógł być udzielony osobie dorosłej, musi ona zostać pouczona o prawdach wiary i obowiązkach chrześcijańskich oraz przejść próbę życia chrześcijańskiego w katechumenacie ${ }^{4}$. Katechumenat zasadniczo opiera się na wskazaniach wydanych przez konferencję biskupów, stanowiących podstawę dla bardziej szczegółowych ustaleń i praktycznych dyspozycji dla biskupa diecezjalnego ${ }^{5}$. W uchwałach synodalnych znajdujemy zarządzenia, zgodnie z którymi Wydział Katechetyczny kurii ma za zadanie opracowanie jednolitych zasad przygotowania dorosłych do sakramentów wtajemniczenia chrześcijańskiego. W każdym dekanacie należy wyznaczyć miejsce w którym takie przygotowania będą prowadzone ${ }^{6}$. Ponieważ ilość osób dorosłych przyjmujących sakramenty wtajemniczenia $\mathrm{w}$ archidiecezji katowickiej nie jest duża, słuszną wydaje się być decyzja, aby ich przygotowanie prowadzone było centralnie, w jednej parafii dekanatu. Należałoby wyznaczać do tego trudnego zadania odpowiednio przygotowanego duszpasterza.

W uchwałach synodu znajduje się też zobowiązanie Wydziału Duszpasterstwa kurii do powołania Archidiecezjalnego Ośrodka

${ }^{3}$ Uchw. 271-273.

${ }^{4}$ KPK 1983, kan. 865 par. 1.

${ }^{5}$ J. Krzywda, Chrzest, w: Komentarz do Kodeksu prawa kanonicznego, red. J. Krukowski, t. III/2, Poznań 2011, s. 52.

${ }^{6}$ Uchw. 274-275. 
Katechumenatu, a także Rejonowych Ośrodków Katechumenatu. Te drugie mają działać w oparciu o bazyliki mniejsze w Katowicach Bogucicach, Mikołowie, Piekarach Śląskich, Pszowie i Rybniku oraz ewentualnie o Szkoły Nowej Ewangelizacji. W nich to katechumeni mogliby przygotowywać się do przyjęcia sakramentów oraz przeżywać okres mistagogii przez rok po otrzymaniu sakramentów inicjacji ${ }^{7}$. Poza drugim z wymienionych dla ośrodków rejonowych zadań, pierwsze, czyli przygotowanie katechumenów zdaje się pokrywać z zadaniem przydzielonym przez Wydział Katechetyczny wszystkim dekanatom. Być może w tym przypadku ich rolą będzie koordynacja działań dekanalnych duszpasterzy, zajmujących się katechumenatem. Nie mniej jednak, powołanie takich ośrodków stanowi niezwykle cenną inicjatywę synodalną.

Zarządza się, aby wprowadzenie w misterium sakramentów inicjacji (w tym oczywiście chrztu i bierzmowania), a także ich celebracja, były dokonywane w parafii zamieszkania dzieci i młodzieży, według jednakowych zasad określonych przez prawo diecezjalne ${ }^{8}$.

Uchwała synodalna powołując się na Wprowadzenie teologiczne i pastoralne do Obrzędów chrztu dzieci $i^{9}$ przypomina, że sakramentu tego należy udzielać w niedziele, podczas Mszy św. Jedynie w sytuacjach wyjątkowych, można chrzcić poza Mszą ${ }^{10}$. Celebrację chrztu sprawuje się według formy wzorcowej, ze szczególnym uwzględnieniem miejsca sprawowania pierwszej części liturgii w pobliżu drzwi świątyni oraz miejsca udzielania sakramentu nad chrzcielnicą lub w jej pobliżü ${ }^{11}$.

Zgodnie z normą Kodeksu prawa kanonicznego zdatnym do godziwego przyjęcia sakramentu bierzmowania jest chrześcijanin, który został odpowiednio pouczony, właściwie dysponowany oraz

\footnotetext{
${ }^{7}$ Uchw. 369; przyp. 200.

${ }^{8}$ Uchw. 282; 286.

${ }^{9}$ Obrzędy chrztu dzieci dostosowane do zwyczajów diecezji polskich, Katowice 2014, nr 9.

${ }^{10}$ Uchw. 371.

${ }^{11}$ Uchw. 368.
} 
ma możliwość odnowienia przyrzeczeń chrzcielnych ${ }^{12}$. To pouczenie, w formie katechezy, powinno być dostosowane do jego wieku i włączone w całokształt pracy duszpastersko-katechetycznej ${ }^{13}$. Do norm kodeksowych nawiązują postanowienia II Synodu Archidiecezji Katowickiej, zarówno w uchwałach wcześniej cytowanych, a dotyczących przygotowania do przyjęcia sakramentów wtajemniczenia chrześcijańskiego, jak i w innych.

Osoby dorosłe, które w odpowiednim dla nich czasie nie przystąpiły do bierzmowania, stanowią specyficzną grupę katechetyczną. Dla nich więc muszą zostać opracowane jednolite, diecezjalne zasady przygotowania. W uchwałach znajduje się zarządzenie, postanawiające aby w każdym dekanacie zorganizowano miejsce przygotowujące dorosłych do bierzmowania ${ }^{14}$. Po raz kolejny postanowienie synodalne dokonują centralizacji przygotowań do sakramentu na poziomie dekanatów. Jest to ważna, a zarazem cenna inicjatywa, pozwalająca na lepsze, bardziej profesjonalne podejście do takiego zadania, poprzez oddelegowanie do niego najbardziej kompetentnego w tej kwestii duszpasterza pracującego w dekanacie.

Norma synodalna nakazuje, podobnie jak ma to miejsce w przypadku przygotowania dzieci do przyjęcia pierwszej Komunii św., aby młodzież pragnąca przystąpić do bierzmowania uczestniczyła w specjalnych, systematycznych katechezach odbywających się w parafiach zamieszkania. Spotkania katechetyczne mają mieć charakter liturgiczno-pastoralny i być prowadzone w oparciu o zasady katechumenatu. Program katechezy parafialnej musi pozostawać w ścisłej relacji z nauczaniem religii w szkole, uzupełniając je zwłaszcza w funkcji wtajemniczenia i wychowania ${ }^{15}$. Można w tym miejscu zapytać, dlaczego katechezy takie nie mogą odbywać się w szkołach, w ramach zajęć szkolnych z religii? Należy tutaj rozróżnić naukę religii i katechezę.

\footnotetext{
${ }^{12}$ Kan. 889 par. 2.

${ }^{13}$ J. KRzYwDA, Bierzmowanie, w: Komentarz do Kodeksu prawa kanonicznego, red. J. Krukowski, t. III/2, Poznań 2011, s. 77-78.

${ }^{14}$ Uchw. 274-275.

${ }^{15}$ Uchw. 283-285.
} 
Zgodnie z Konkordatem, Państwo gwarantuje, że szkoły publiczne prowadzone przez organy administracji państwowej i samorządowej, organizują naukę religii w ramach zajęć szkolnych ${ }^{16}$. Według obowiązującego Kodeksu prawa kanonicznego nauczanie religii odbywa się w różnego rodzaju szkołach, w tym również państwowych, a Kościół sprawuje nad nim jedynie nadzór. Natomiast za katechezę jest odpowiedzialny głównie proboszcz (w imieniu Wspólnoty Kościoła) na terenie powierzonej sobie parafii ${ }^{17}$. Podczas lekcji religii przekazuje się głównie wiedzę dotyczącą wiary katolickiej, na katechezie natomiast wiarę, aby jak podaje norma kodeksowa, „aby przez przyjmowanie nauki i doświadczenia życia chrześcijańskiego stawała się żywa, wyraźna i czynna"18. Dla owocnego przyjęcia sakramentu bierzmowania nie wystarcza jedynie zdobycie wiedzy, konieczne jest przede wszystkim pogłębienie wiary kandydata, by podniosła się z poziomu dziecięcego na poziom dorosłego, już świadomego chrześcijanina.

W uchwałach synodalnych znajdujemy również zalecenie, aby uzupełniającą, praktyczną formą przygotowania do przyjęcia bierzmowania, a także działania po jego przyjęciu stał się wolontariat młodzieży ${ }^{19}$. Skoro sakrament ten zobowiązuje przyjmujących, do świadczenia o Chrystusie ${ }^{20}$, to właśnie uczestnict wo w wolontariacie, czyli dobrowolnej, nieodpłatnej pomocy bliźniemu znakomicie do tego przygotowuje, stając się równocześnie widocznym świadectwem życia chrześcijańskiego człowieka umocnionego darami Ducha św. Cennym uzupełnieniem przygotowań do sakramentu jest również proponowanie młodzieży udziału w spotkaniach ruchów i stowarzyszeń młodzieżowych ${ }^{21}$.

Synod zaleca również kontynuację parafialnych spotkań katechetycznych, po przystąpieniu młodzieży do bierzmowania, w ramach

\footnotetext{
${ }^{16}$ Dz. U. 1998, nr 51, poz. 318; szerzej na ten temat w: K. WARCHAŁowski, Nauczanie religii i szkolnictwo katolickie w konkordatach współczesnych, Lublin 1998, s. 112-118.

${ }^{17}$ Por. kan. 804, 776-777.

${ }^{18}$ Kan. 773.

${ }^{19}$ Uchw. 451.

${ }^{20}$ Por. Kan. 879.

${ }^{21}$ Uchw. 102.
} 
katechezy mistagogicznej ${ }^{22}$. Spotkania takie przyczyniają się bowiem do utrzymywania przez młodzież bliższych kontaktów ze swoją parafią i duszpasterzami, włączając mocniej w życie parafialne.

\section{Eucharystia}

Kolejnym sakramentem, do którego odnoszą się postanowienia synodu jest Eucharystia. Wiele $\mathrm{z}$ nich posiada charakter zaleceń. Zaleca się zatem, aby w każdej parafii powołać zespół liturgiczny, którego zadaniem będzie wspólne przygotowanie liturgii niedzielnej. Grupa ta może również przygotowywać pewne elementy formacji liturgicznej, poprzez które wyjaśniane będą wiernym kolejne części liturgii, na przykład postawy liturgiczne na Mszy św. W skład zespołu powinni wchodzić duszpasterze, służba liturgiczna oraz przedstawiciele wspólnot parafialnych. Przygotowanie liturgii niedzielnej ma dążyć, aby w miarę możliwości na wszystkich Mszach zaangażować wiernych świeckich do pełnienia posług. Ma to również związek z innym zaleceniem skierowanym do proboszczów, aby dbali o jednolitość czynionych przez wiernych znaków i postaw liturgicznych oraz ich zgodność z przepisami liturgicznymi ${ }^{23}$. Takie działania powinny ubogacić niedzielną liturgię w świątyniach, a ponadto zwiększyć odpowiedzialność osób wchodzących w skład zespołu liturgicznego za oprawę Mszy we własnej parafii.

Zaleca się także, aby dziekani, we współpracy z proboszczami dekanatu i parafialnymi radami duszpasterskimi opracowali plan celebrowania niedzielnych i świątecznych Mszy św., uwzględniający rytm życia i wypoczynku wiernych ${ }^{24}$. Przepis ten nie jest jasny, najlepsze rozeznanie w odniesieniu do godzin rozpoczęcia odprawiania Mszy posiadają przecież proboszczowie. Wydaje się, że ustawodawcy chodzi tutaj o plan, w którym uwzględnione zostaną różne godziny celebracji Eucharystii w poszczególnych parafiach, niejako zsynchronizowane ze sobą. Budzi to jednak pewne wątpliwości, ponieważ takie działania

\footnotetext{
${ }^{22}$ Uchw. 291.

${ }^{23}$ Uchw. 372; 374.

${ }^{24}$ Uchw. 373.
} 
wspierają pośrednio tzw. „churching”, czyli uczestnictwo wiernych w Eucharystii w różnych świątyniach, co osłabia ich więzi z własną parafią. Należy zadbać, aby przynajmniej jedna Msza niedzielna miała charakter bardziej uroczysty, czyli była celebrowana z pełną asystą liturgiczną, starannie przygotowanymi śpiewami, uroczystą procesją wejścia, użyciem kadzidła itp. W katedrze oraz bazylikach mniejszych archidiecezji należy przynajmniej raz w miesiącu odprawiać Mszę św. w języku łacińskim. Natomiast we wszystkich parafiach uczyć wiernych podstawowych śpiewów gregoriańskich (Kyrie, Sanctus, Agnus Dei, Pater noster $)^{25}$. Przywracanie niejako mszy łacińskich wiąże się z faktem, iż język łaciński w dalszym ciągu pozostaje podstawowym językiem w liturgii Kościoła rzymskokatolickiego ${ }^{26}$. Ponadto uczestnictwo grup pielgrzymkowych z diecezji katowickiej we Mszach św. celebrowanych przez papieża wymaga znajomości podstawowych modlitw w tym języku.

Uchwały synodalne nawiązują także do śląskiej tradycji procesji ofiarnej, zalecając jej zachowanie ${ }^{27}$. Chodzi tutaj o procesję zazwyczaj odbywającą się wokół ołtarza przedsoborowego, w czasie której wierni składają ofiary do puszki, znajdującej się z tyłu wspomnianego ołtarza.

Kolejna dyspozycja dotyczy Komunii św. pod dwiema postaciami. Zaleca się taką formę Jej udzielania podczas Mszy Wieczerzy Pańskiej oraz Wigilii Paschalnej, a także w Boże Ciało i Eucharystii sprawowanej w tygodniu dla mniejszych grup wiernych. Prezbiterzy przewodniczący celebracji liturgicznej otrzymują uprawnienie do podejmowania decyzji o udzielaniu Komunii pod dwiema postaciami ${ }^{28}$. Zgodnie z normą kanoniczną, Komunii św. należy udzielać tylko pod postacią chleba, albo zgodnie z przepisami liturgicznymi, pod obiema postaciami ${ }^{29}$. Sytuacje w których dopuszczana jest interesująca nas forma komuni-

\footnotetext{
${ }^{25}$ Uchw. 375; 379.

${ }^{26}$ Por. M. PAstuszko, Najświętsza Eucharystia według Kodeksu prawa kanonicznego Jana Pawła II, Kielce 1997, s. 257; kan. 928.

${ }^{27}$ Uchw. 380.

${ }^{28}$ Uchw. 376.

${ }^{29}$ Kan. 925.
} 
kowania wiernych określiła Kongregacja Kultu Bożego, Konferencja Episkopatu Polski oraz poszczególni biskupi diecezjalni ${ }^{30}$. Przepis II Synodu Archidiecezji Katowickiej przekazuje możliwość podjęcia decyzji w omawianej kwestii kapłanowi, który przewodniczy liturgii mszalnej. Tylko on bowiem w konkretnej sytuacji może ocenić, czy udzielanie Eucharystii pod postaciami chleba i wina będzie pożyteczne i godne. Dotyczy to jednak przypadków wymienionych powyżej taksatywnie. Zaleca się, aby w każdej parafii liczba nadzwyczajnych szafarzy Komunii św. była odpowiednia do potrzeb wspólnoty ${ }^{31}$. Interpretując powyższe zalecenie, należy zauważyć, że nie we wszystkich parafiach archidiecezji muszą być powołani szafarze nadzwyczajni. Kiedy bowiem wspólnota parafialna nie posiada potrzeby korzystania $\mathrm{z}$ ich pomocy, nie ma też konieczności ich zatrudniania.

Archidiecezjalne Centrum Formacji Pastoralnej zobowiązane jest do opracowania szczegółowego programu formacji tych osób, a także przygotowujących się do przyjęcia posługi lektora i akolity, niebędących alumnami seminarium duchownego i innych członków służby liturgicznej. Ponadto należy podtrzymywać zwyczaj wykonywania posługi ministrantów przez chłopców, młodzieńców i mężczyzn ${ }^{32}$. Czytania liturgii słowa podczas Mszy św., nawet jeżeli jest to liturgia z udziałem dzieci, powinny być wykonywane przez osoby dorosłe ${ }^{33}$. Norma jest uzasadniona, ponieważ powaga celebracji domaga się przekazywania Bożego Słowa w sposób wyraźny, zrozumiały dla słuchaczy, autorytatywny, co zasadniczo może być zapewnione przez specjalnie do tego przygotowanych lektorów, lub inne osoby dorosłe.

Uchwały synodalne nawiązują również do tzw. wczesnej Komunii dzieci, czyli praktyki diecezjalnej przystępowania dzieci w wieku około 6 lat do Eucharystii po raz pierwszy w życiu. Tradycję taką należy pielęgnować i usilnie do niej zachęcać, pamiętając równocześnie,

\footnotetext{
${ }^{30}$ E. Górecki, Najświętsza Eucharystia, w: Komentarz do Kodeksu prawa kanonicznego, red. J. Krukowski, t. III/2, Poznań 2011, s. 109-110.

${ }^{31}$ Uchw. 413.

${ }^{32}$ Uchw. 410-412.

${ }^{33}$ Uchw. 377.
} 
że do wczesnej Komunii św, dopuszcza się dzieci tych rodziców, którzy dają moralną pewność troski o rozwój życia eucharystycznego i religijno-moralnego swojego potomstwa. Roztropności pastoralnej proboszczów pozostawia się dopuszczenie do wcześniejszej Eucharystii dzieci rodziców żyjących w związkach niesakramentalnych. Tekst synodalny powołuje się w tym miejscu na kan. 913 par. 1 o przystępowaniu dzieci do omawianego sakramentu ${ }^{34}$. W odniesieniu do cytowanej dyspozycji pojawiają się jednak poważne wątpliwości. Prawo zwyczajowe dopuszczało bowiem dotychczas do wczesnej Komunii wyłącznie dzieci rodziców, których życie gwarantowało niejako wspomnianą pewność moralną. Było to swojego rodzaju wyróżnienie dla rodziny, a zarazem widoczny znak dla innych, całej wspólnoty parafialnej, że we współczesnym świecie możliwe jest prowadzenie życia rodzinnego zgodnego z zasadami wiary katolickiej. Dopuszczając teraz dzieci z tzw. rodzin rozbitych, daje się sygnał, że Kościołowi, przynajmniej na terenie archidiecezji katowickiej, być może nie zależy już tak bardzo na promocji typowo chrześcijańskiej rodziny. Takiej decyzji nie można też usprawiedliwiać jakąkolwiek krzywdą czynioną dziecku, bowiem ma ono w dalszym ciągu możliwość przyjęcia pierwszej Komunii św. wraz z większością rówieśników w swojej parafii.

Postanowienia synodalne odnoszą się także do celebracji Triduum Paschalnego. Wigilię Paschalną można rozpoczynać dopiero po zapadnięciu zmroku, najwcześniej o godzinie 20, jadnak nie później, aby zakończyć ją przed świtem. W czasie liturgii męki Pańskiej należy, ze względu na czytelność znaku, używać do adoracji tylko jednego krzyża. Błogosławieństwo pokarmów w Wielką Sobotę warto rozpoczynać od adoracji Najświętszego Sakramentu ${ }^{35}$. Norma prawa kanonicznego zaleca bowiem, organizowanie kościołach i kaplicach przez odpowiedni czas wystawienia Najświętszego Sakramentu, aby miejscowa wspólnota głębiej rozważała i adorowała tajemnicę eucharystyczną ${ }^{36}$.

\footnotetext{
${ }^{34}$ Uchw. 378.

${ }^{35}$ Uchw. 395-399.

${ }^{36}$ Kan. 942.
} 
Synod nakazuje oddzielanie nabożeństw eucharystycznych od nieszporów w niedziele i uroczystości. Podczas nabożeństw eucharystycznych wolno używać tylko jednej monstrancji z Najświętszym Sakramentem (np. do błogosławieństwa lurdzkiego). Trzeba zadbać o chrystocentryczny charakter nabożeństw, zwłaszcza odprawianych $\mathrm{z}$ monstrancją, $\mathrm{w}$ tym również różańcowego. Natomiast w ciągu dnia należy w parafiach organizować grupy osób adorujących Najświętszy Sakrament, stąd też świątynie muszą pozostawać otwarte dla wiernych ${ }^{37}$.

W odniesieniu do przestrzeni sakralnej świątyni zarządza się, aby w każdej z nich oprócz ołtarza i ambony znajdowało się również miejsce przewodniczenia. Tej funkcji nie powinna pełnić ambona. Nie należy tworzyć w prezbiterium tak zwanych tronów Słowa Bożego, a już istniejące usunąć $w$ trakcie renowacji prezbiterium ${ }^{38}$. Trzeba zauważyć, że Ogólne wprowadzenie do Mszału Rzymskiego wspominając o miejscu przewodniczenia określa tym mianem krzesło kapłana celebransa, uwydatniające jego funkcję przewodniczącego zgromadzenia i kierującego modlitwą, u szczytu prezbiterium, zwrócone w stronę ludu ${ }^{39}$. W wielu świątyniach przyjęło się ze względów praktycznych, że przed lub obok tego krzesła stawia się pulpit, na którym umieszczone zostają teksty liturgiczne używane podczas początkowych i końcowych części liturgii mszalnej. Pulpit nie jest jednak konieczny, o ile służba liturgiczna może trzymać przed celebransem mszał, tak jak to ma miejsce między innymi podczas wzorcowej liturgii papieskiej.

\section{Sakramenty uzdrowienia}

Do grupy sakramentów uzdrowienia należą pokuta i namaszczenie chorych. Norma kodeksowa stanowi, że każdy duszpasterz ma obowiązek zadbać o to, aby wierni mogli się wyspowiadać kiedy w sposób uzasadniony o to proszą, mając sposobność przystąpienia do

\footnotetext{
${ }^{37}$ Uchw. 390; 392; 402; 404.

${ }^{38}$ Uchw. 405-406.

${ }^{39}$ Nowe Ogólne wprowadzenie do Mszału Rzymskiego, Poznań 2004, nr 310.
} 
spowiedzi w dogodnych dla nich dniach i godzinach ${ }^{40}$. Wspomniane dni i godziny stanowią minimum dla spowiednika, który przyjmuje wyznanie grzechów także poza nimi, kiedy zachodzi taka potrzeba, na przykład dla postępu w życiu duchowym penitentów, z pobożności lub konieczności. W sposób nieuzasadniony prosi o spowiedź wierny, chcący się wyspowiadać bez uzasadnionej racji o niezwykłej godzinie, lub więcej niż raz na dzień ${ }^{41}$.

W celu ustalenia pewnego porządku w parafii, szczególnie dla owocnego sprawowania sakramentów, uchwały synodalne stanowią, iż zachowuje się tradycję spowiadania pół godziny przed każdą Mszą św. Ponadto zawierają zachętę, aby wychowywać wiernych do przystępowania do spowiedzi przed rozpoczęciem Eucharystii, a nie w trakcie jej celebrowania ${ }^{42}$. Czyni to zadość zasadzie, według której $\mathrm{w}$ danym momencie sprawuje się w świątyni tylko jeden sakrament, a nie równocześnie kilka obok siebie.

Wśród postanowień synodu znajdujemy również zalecenie stworzenia wiernym okazji do spowiedzi także w późniejszych godzinach wieczornych, zwłaszcza w okresie Adwentu i Wielkiego Postu ${ }^{43}$. Zalecenie to wpisuje się niejako w modne od pewnego czasu tzw. „noce konfesjonałów”, kiedy penitenci mają możliwość przystępowania do sakramentu pokuty w późnych godzinach wieczornych, a nawet nocą. Dobrze, że jest to jedynie zalecenie i nie każdy proboszcz musi je wprowadzać w swojej parafii. Należy się bowiem zastanowić, czy działania duszpasterskie powinny iść w tym samym kierunku co handlowe i podobnie jak duże supermarkety zapraszać klientów do realizowania ich potrzeb konsumenckich w dowolnym czasie, nawet późno wieczorem. Wierni mają zdawać sobie sprawę z tego, że kupno odzieży lub żywności jest czymś zupełnie innym niż przyjmowanie sakramentów, które mogą otrzymać jedynie dzięki niezasłużonej łasce Jezusa Chrystusa, a nie kiedy właśnie przyjdzie im na to ochota, nawet

\footnotetext{
${ }^{40}$ Kan. 986 par. 1.

${ }^{41}$ M. Pastuszko, Sakrament pokuty i pojednania, Kielce 1999, s. 423-424.

${ }^{42}$ Uchw. 381.

${ }^{43}$ Uchw. 383.
} 
w nocy. Takie podejście może rodzić u nich postawy roszczeniowe, że sakramenty należą się każdemu i o każdej porze.

Natomiast bardzo słusznie, w okresie Adwentu i Wielkiego Postu zaleca się wspólnotową celebrację sakramentu pokuty i pojednania, $\mathrm{z}$ indywidualnym rozgrzeszeniem oraz nabożeństw pokutnych ${ }^{44}$. Wydaje się, że powinno to być nie tyle zalecenie, ale nawet zarządzenie. Taka forma sprawowania sakramentu podczas specjalnego nabożeństwa pokutnego pozwala z jednej strony lepiej przygotować się penitentom do spowiedzi, $\mathrm{z}$ drugiej zaś wydaje się być niejako mniej nużąca dla spowiedników, którzy przed świętami Bożego Narodzenia i Wielkanocy w krótkim czasie muszą wyspowiadać często ogromną liczbę wiernych ${ }^{45}$.

W wybranej parafii dekanatu lub większego miasta zaleca się dziekanom, aby we współpracy z proboszczami i parafialnymi radami duszpasterskimi, zorganizowali tak zwany stały konfesjonał, czyli miejsce w którym przez dłuższy okres w ciągu dnia będzie dyżurował spowiednik, aby osoba potrzebująca jego pomocy mogła przystąpić do omawianego sakramentu ${ }^{46}$.

Dosyć rewolucyjną zmianą w prawie diecezjalnym jest natomiast zniesienie obowiązku poświadczania przez podpis spowiednika przystąpienia do spowiedzi. Wymaganie takowe zostaje bowiem zniesione $^{47}$. Obowiązek ten, jak uważa Pastuszko, istniał na terenach dzisiejszej Polski przynajmniej od początku XX w. ${ }^{48}$ Sprzeciwiał się mu między innymi Sobański, argumentując, że próba kontroli zachowania zewnętrznego sięga w tym przypadku aktu wewnętrznego, ze swojej istoty niepodlegającemu kontroli ${ }^{49}$. Marcol dodaje natomiast, iż

\footnotetext{
${ }^{44}$ Uchw. 382.

${ }^{45}$ Z. JANCZEWsKi, Sprawowanie sakramentu pokuty i pojednania w świetle prawa kanonicznego i liturgicznego, z uwzględnieniem specyfiki warunków polskich, Prawo Kanoniczne 49(2006) nr 1-2, s. 189-190.

${ }^{46}$ Uchw. 384.

${ }^{47}$ Uchw. 385.

${ }^{48}$ M. Pastuszko, Sakrament pokuty..., dz. cyt., s. 510.

${ }^{49}$ R. Sobański, Zaświadczenie o spowiedzi przedślubnej, Prawo Kanoniczne 37(1994) nr 3-4, s. 264.
} 
wymagając od kogoś kartki potwierdzającej przystąpienie do spowiedzi, usiłujemy niejako zmusić go do przyjęcia tego sakramentu, co jest równocześnie cichym oskarżeniem, że dopuścił się ciężkiego grzechu, po popełnieniu którego nie można przystąpić do Komunii św., czy innych sakramentów ${ }^{50}$. Niestety zniesienie omawianego obowiązku, pociągnie za sobą niebezpieczeństwo pojawienia się u osób o słabej wierze, pokusy przystępowania do sakramentów, bez wcześniejszego odpuszczenia ciążącego na ich sumieniu grzechu ciężkiego np. podczas jakiejś uroczystości rodzinnej.

Należy dodać, iż uchwały synodalne zalecają wiernym, aby regularnie przyjmowali omawiany sakrament oraz w miarę możliwości korzystali z posługi stałych spowiedników i kierownictwa duchowego ${ }^{51}$.

Kolejne zalecenia odnoszą się do sakramentu namaszczenia chorych. Należy dbać o to aby przyjmowały go osoby chore, lub w podeszłym wieku. Wskazane jest udzielanie go przy okazji odwiedzin chorych w domach, pielęgnując zwyczaj odbywania tego w pierwsze soboty miesiąca. Należy unikać zasady periodyczności (przyjmowania raz do roku), kierując się natomiast kryterium stanu zdrowia lub podeszłego wieku ${ }^{52}$. O podmiocie wspomnianego sakramentu, jako osobie w podeszłym wieku mówi się, kiedy bardzo podupadła na siłach, choć nie zachodzi podejrzenie o ciężką chorobę. Namaszczanie wiernych po ukończeniu określonego wieku (np. 70 lat) byłby wypaczeniem myśli prawodawcy. Osoby chore to takie, które zapadły na poważną, czyli niebezpieczną dla życia chorobę ${ }^{53}$. Jedynie te kryteria uprawniają wiernego do przyjęcia namaszczenia chorych, nie można natomiast udzielać namaszczenia wszystkim w podeszłym wieku, obecnym podczas dorocznych nabożeństw z okazji dni chorych.

\footnotetext{
${ }^{50}$ A. Marcol, Pokuta i sakrament pokuty, Opole 1992, s. 110.

${ }^{51}$ Uchw. 41.

${ }^{52}$ Uchw. 387; 389.

${ }^{53}$ W. Zubert, Sakrament namaszczenia chorych, w: Komentarz do Kodeksu prawa kanonicznego, red. J. Krukowski, t. III/2, Poznań 2011, s. 199-200.
} 
Należy również przypomnieć, że przyjmujący ten sakrament, o ile jest w stanie, powinien wcześniej przystąpić do spowiedzi.

\section{Sakrament święceń}

Prawo powszechne stanowi, że kandydaci do święceń diakonatu i prezbiteratu muszą wcześniej być uformowani, przez dokładne przygotowanie zgodne z prawem. Ponadto ustawodawca nakłada na biskupa diecezjalnego obowiązek troski, aby kandydaci zostali pouczeni o samych święceniach i obowiązkach z nich wynikających ${ }^{54}$. Formacja taka dokonuje się zazwyczaj w seminariach duchownych. Stąd również w Uchwałach II Synodu Archidiecezji Katowickiej znalazły się normy dotyczące przyjęcia powyższego sakramentu.

Zarządza się zatem, aby w Wyższym Śląskim Seminarium Duchownym kontynuować okres propedeutyczny dla alumnów ${ }^{55}$. Obejmuje on pełny rok formacyjny, podczas którego mają oni możliwość osobistej formacji ludzkiej, duchowej i wspólnotowej, pod kierunkiem moderatorów i ojców duchownych wskazanych przez arcybiskupa katowickiego. Nadzór nad prowadzeniem okresu propedeutycznego sprawuje rektor seminarium. Czas ten alumni spędzają poza główną siedzibą seminarium, w specjalnym ośrodku formacyjnym ${ }^{56}$.

W trakcie okresu propedeutycznego, a także późniejszej formacji seminaryjnej należy wspierać proces budowania relacji interpersonalnych i integracji grupy, poprzez formację duchową, prowadzoną przez ojców duchownych, oraz w razie potrzeby, przy wsparciu psychologów ${ }^{57}$. Norma kładzie silny nacisk na relacje interpersonalne pomiędzy alumnami, w tym współpracę w grupach, ponieważ, takie umiejętności konieczne będą przyszłym kapłanom podczas ich pracy duszpasterskiej w odniesieniu do powierzonych im wiernych, a także kolegów, przyjaciół i znajomych. W kształtowaniu wspomnianych relacji biorą udział tradycyjnie ojcowie duchowni oraz, w razie potrzeby,

\footnotetext{
${ }^{54}$ KPK1983, kan. 1027-1028.

${ }^{55}$ Uchw. 178.

${ }^{56}$ Wstuchani w Ducha. Uchwały II Synodu..., przyp. 90, s. 59.

${ }^{57}$ Uchw. 179.
} 
psychologowie. Udział tych drugich jest odpowiedzią na zmieniającą się w XXI wieku rzeczywistość, a także wykorzystaniem nowoczesnej wiedzy z zakresu psychologii do kształtowania przyszłych kapłanów. Ponadto do przyjęcia święceń prawo powszechne wymaga zaświadczenia o stanie zdrowia psychicznego kandydata ${ }^{58}$.

Zaleca się wprowadzenie w seminarium stażu duszpasterskiego dla alumnów, trwającego jeden semestr. Odbywać się on ma w parafiach archidiecezji katowickiej oraz obejmować alumnów przed Admissio. Celem stażu będzie doświadczenie realiów życia kapłańskiego oraz lepsze przygotowanie praktyczne do pracy duszpasterskiej. W jego trakcie alumni kontynuują studia teologiczne ${ }^{59}$.

W ramach formacji seminaryjnej alumni drugiego roku kierowani są na obowiązkowy staż pracy w szpitalach, lub placówkach „Caritas”. Zaleca się ponadto organizowanie misyjnych staży kleryckich, we współpracy i przy wsparciu osób odpowiedzialnych za krzewienie ducha misyjnego w Kościele lokalnym. Kolejnym zaleceniem jest podejmowanie przez alumnów, zasadniczo w czasie wakacji letnich, praktyk ewangelizacyjnych, poprzez włączanie się w działalność grup ewangelizacyjnych ${ }^{60}$.

Oprócz zdobywania wiedzy uniwersyteckiej na Wydziale Teologicznym zaleca się, aby alumni uczestniczyli, w ramach studium domesticum, w dodatkowych zajęciach koniecznych dla właściwej formacji oraz należytego przygotowania duszpasterskiego ${ }^{61}$. Wspomniane studium stanowi narzędzie formacji intelektualnej w strukturach ich przygotowania w seminarium duchownym ${ }^{62}$.

Osoby prowadzące zajęcia dydaktyczne na Wydziale Teologicznym Uniwersytetu Śląskiego powinny wykorzystywać ćwiczenia z alumnami do inicjowania dyskusji oraz zdobywania przez nich umiejętności uzasadniania posiadanych poglądów. Władzom wydziału

\footnotetext{
${ }^{58}$ Kan. 1051.

${ }^{59}$ Uchw. 181.

${ }^{60}$ Uchw. 185-186; 188.

${ }^{61}$ Uchw. 182.

${ }^{62}$ Wsłuchani w Ducha. Uchwały II Synodu..., dz. cyt., przyp. 91, s. 60.
} 
zaleca się poszerzenie programu kształcenia o zagadnienia z wiedzy o mediach, wprowadzenie ćwiczeń dotyczących głoszenia kerygmatu i współpracy ze świeckimi w dziele ewangelizacji oraz wykładów z prawa wyznaniowego ${ }^{63}$. W odniesieniu do powyższych dyspozycji może dziwić, że powołując się na wytyczne Kongregacji do spraw Wychowania Katolickiego uchwała synodalna została sformułowana $\mathrm{w}$ formie zalecenia a nie zarządzenia.

Do święceń należy dopuszczać tylko osoby, które zostały uznane za zdatne do ich przyjęcia ${ }^{64}$. Podmiotem kompetentnym do rozpoznawania zdatności kandydatów jest jego biskup własny lub inny wyższy przełożony. Potrzebna jest do tego opinia o kandydacie, wydawana przez rektora seminarium, rady pedagogicznej tej instytucji, proboszcza parafii zamieszkania itp. ${ }^{65}$ Uchwała synodalna zaleca, aby podtrzymywać dotychczasową praktykę konsultowania z duchownymi, prowadzącymi zajęcia na Wydziale Teologicznym kwestii zdatności alumnów do przyjęcia święceńn ${ }^{66}$.

\section{Małżeństwo}

Zawarcie małżeństwa sakramentalnego wymaga szczególnego przygotowania nupturientów. Kodeks prawa kanonicznego podkreśla potrzebę troski duszpasterskiej o przygotowanie wiernych do małżeństwa i życia w rodzinie. W tym zakresie nakłada określone obowiązki na duszpasterzy, zwracając uwagę na potrzebę świadczenia różnorodnej pomocy duchowej. Prawodawca wskazuje także na podmioty troski duszpasterskiej o należyte przygotowanie wiernych do omawianego sakramentu. Obowiązek ten spoczywa w pierwszym rzędzie na duszpasterzach (biskupach diecezjalnych i proboszczach) i związanych z nimi wspólnotach (diecezjach oraz

\footnotetext{
${ }^{63}$ Uchw. 192-193.

${ }^{64}$ Por. KPK1983, kan. 1029.

${ }^{65}$ J. Krukowski, Święcenia, w: Komentarz do Kodeksu prawa kanonicznego, red. J. Krukowski, t. III/2, Poznań 2011, s. 226-227.

${ }^{66}$ Uchw. 183.
} 
parafiach) ${ }^{67}$. Organizowaniem form pomocy dla wiernych, zarówno przed zawarciem małżeństwa, jak i później, zobowiązany jest zająć się w skali diecezji ordynariusz miejsca, mogąc przy tym wysłuchać opinii kompetentnych i doświadczonych osób świeckich ${ }^{68}$. Wolno dopatrzyć się tutaj sugestii wydania przez biskupa diecezjalnego odpowiednich norm prawnych w tej dziedzinie ${ }^{69}$.

Wyrazem powyżej wspomnianej troski są normy zawarte w uchwałach omawianego synodu, będące owocem długich konsultacji interesujących nas kwestii w gronie osób duchownych i świeckich biorących udział w sesjach synodalnych. Mają one przede wszystkim formę zarządzeń. A zatem, zarządza się realizację przez Wydział Duszpasterstwa Rodzin następujących zadań:
a) przygotowania materiałów pomocniczych dla parafialnego duszpasterstwa małżeństw i rodzin,
b) naboru, stałej formacji oraz rozwijania wiedzy i umiejętności doradców życia rodzinnego, weryfikacji ich kompetencji zwią- zanych z udzielaniem im i przedłużaniem misji kanonicznej,
c) systematycznej weryfikacji i uaktualniania form bliższego i bez- pośredniego przygotowania do małżeństwa,
d) ewaluacji przygotowania bliższego i bezpośredniego do mał- żeństwa przez przeprowadzanie odpowiednich ankiet,
e) dbałości o dostępność i jakość poradnictwa rodzinnego $\mathrm{w}$ archidiecezji,
f) rozwijania profesjonalnych struktur formacji i wsparcia mał- żeństw i rodzin oraz zorganizowania rejonowych, specjalistycz- nych poradni rodzinnych,
g) współpracy z ruchami i stowarzyszeniami działającymi na rzecz małżeństwa,
h) uwzględniania tematyki duszpasterstwa małżeństw i rodzin w ramach stałej corocznej formacji prezbiterów,

\footnotetext{
${ }^{67}$ W. Góralski, Małżeństwo, w: Komentarz do Kodeksu prawa kanonicznego, red. J. Krukowski, t. III/2, Poznań 2011, s. 259-260; Kan. 1063.

${ }^{68}$ KPK1983, kan. 1064.

${ }^{69}$ W. Góralski, dz. cyt., s. 261.
} 
i) powołania przy wspomnianym wydziale, Rady Wydziału Duszpasterstwa Rodzin, diagnozującej aktualne potrzeby duszpasterskie w omawianej materii oraz wytyczającej w niej nowe kierunki i cele duszpasterskie ${ }^{70}$.

Do zadań wydziału należy zatem nie tylko przygotowanie różnych kierunków formacji grup wiernych do małżeństwa i rodziny, ale także funkcja weryfikacyjna w odniesieniu do podmiotów zajmujących się omawianymi kwestiami - ocena kompetencji, monitorowanie przy pomocy ankiet, diagnozowanie nowych potrzeb.

Jedna z norm synodalnych nakazuje dekanalnym duszpasterzom rodzin, przy wsparciu własnego dziekana, koordynowanie im powierzonego duszpasterstwa. Są oni powoływani przez Arcybiskupa Metropolitę Katowickiego na wniosek dyrektora Wydziału Duszpasterstwa Rodzin ${ }^{71}$. Natomiast rolą proboszcza jest organizacja przygotowania dalszego, bliższego i bezpośredniego do sakramentu małżeństwa, prowadzenie poradni życia rodzinnego, integrowanie rodzin we własnej parafii, na przykład przez organizację specjalnej katechezy dla rodziców dzieci przystępujących do pierwszej Komunii i bierzmowania. Zaleca się również, aby proboszczowie zorganizowali duszpasterstwo małżeństw i rodzin znajdujących się w sytuacjach wyjątkowych i nieprawidłowych (rodziny rozbite, związki niesakramentalne, konkubinaty). Innym zaleceniem jest podjęcie współpracy z podmiotami i organizacjami działającymi na rzecz rodziny, ze szczególnym uwzględnieniem samorządów. Dotyczy to również zadania przygotowania do małżeństwa ${ }^{72}$. Dwa ostatnie zalecenia wydają się być szczególnie cenne. W obliczu narastającego zjawiska małżeństw rozbitych i powiększającej się w związku z tym liczby związków niesakramentalnych, powstawanie duszpasterstwa, ukierunkowanego na takich wiernych może przyczynić się do ich mocniejszego zbliżenia do Boga i Kościoła, przez pogłębianie wiedzy i świadomości o ich sytuacji i świadczoną w tej dziedzinie pomoc.

\footnotetext{
${ }^{70}$ Uchw. 64-66.

${ }^{71}$ Uchw. 70.

${ }^{72}$ Uchw. 72-73; 75.
} 
Współpraca z samorządami może stać się dla nich inspiracją do podejmowania nowych działań na rzecz budowania w społeczeństwie zdrowej rodziny.

Następne zalecenia dotyczą opracowania programów nauczania i koniecznych wskazań duszpasterskich. Wydział Duszpasterstwa Rodzin we współpracy z Wydziałem Teologicznym Uniwersytetu Śląskiego powinny opracować wspólnie programy nauczania realizowane w ramach wspomnianej instytucji kurialnej, kształcenia uniwersyteckiego na kierunku nauki o rodzinie, teologicznych studiów podyplomowych oraz programy współpracy w dziedzinie badań naukowych ${ }^{73}$. Te ostatnie znakomicie wpisują się w kierunki rozwoju nauki w Polsce, czyli współpracę jednostek naukowo-badawczych z instytucjami wdrażającymi poźniej te badania w życie.

Inne bardzo cenne zalecenie dotyczy wypracowania przez wyżej wspomniany wydział kurialny wskazań dla proboszczów, dotyczących pracy duszpasterskiej z rodzinami i osobami dotkniętymi skutkami emigracji zarobkowej ${ }^{74}$. Takich osób od pewnego czasu przybywa w parafiach w znacznym tępie. Młodzież wyjeżdżająca na emigrację zarobkową pragnie zakładać rodziny, a przy tym zawierać małżeństwa sakramentalne w swoim kościele parafialnym. Łączy się to między innymi z problemem przygotowania tych ludzi do małżeństwa, na które, jak często twierdzą, nie mają zbyt wiele czasu przebywając krótko w Polsce i równocześnie nie mając możliwości takiego przygotowania za granicą (z braku znajomości języka, dużej odległości do najbliższej parafii katolickiej). Opracowanie wytycznych o których wspomina norma synodalna, stało się więc niejako koniecznością i powinnością duszpasterską.

\section{Zakończenie}

Kodeks prawa kanonicznego nakłada na duszpasterzy i pozostałych wiernych obowiązek troski o to, aby proszący o sakramenty zostali przygotowani do ich przyjęcia. Normy takie znalazły się w Uchwałach

\footnotetext{
${ }^{73}$ Uchw. 67.

${ }^{74}$ Uchw. 69.
} 
II Synodu Archidiecezji Katowickiej. Kładą one przede wszystkim mocny nacisk na przygotowanie proszących o sakrament, a także ich rodziców. W parafiach archidiecezji należy prowadzić specjalne katechezy dla rodziców dzieci, mających przystąpić do sakramentu chrztu, bierzmowania i Eucharystii. Spotkania z rodzicami są praktykowane od dawna, jednakże teraz, zamiast formy przekazywania im informacji organizacyjnych czy wychowawczych, powinny przyjąć one strukturę katechezy dorosłych.

Wydział Katechetyczny kurii ma za zadanie opracowanie jednolitych zasad przygotowania dorosłych do sakramentów wtajemniczenia chrześcijańskiego. W każdym dekanacie należy wyznaczyć miejsce, w którym takie katechezy będą prowadzone. Zarządza się, aby wprowadzenie w misterium sakramentów inicjacji, a także ich celebracja, były dokonywane w parafii zamieszkania dzieci i młodzieży, według jednakowych zasad określonych przez prawo diecezjalne.

Osoby dorosłe, które w odpowiednim dla nich czasie nie przystąpiły do bierzmowania, stanowią specyficzną grupę katechetyczną. Dla nich więc muszą zostać opracowane jednolite, diecezjalne zasady przygotowania. W uchwałach znajduje się również zarządzenie postanawiające, by w każdym dekanacie zorganizowano miejsce przygotowujące dorosłych do bierzmowania. Należy w tym miejscu zauważyć, że postanowienia synodalne dokonują centralizacji przygotowań do sakramentu na poziomie dekanatów, jest to ważna, a zarazem cenna inicjatywa. W uchwałach znajdujemy również zalecenie, aby uzupełniającą, praktyczną formą przygotowania do bierzmowania, a także działania po jego przyjęciu, stał się wolontariat młodzieży, skoro sakrament ten zobowiązuje przyjmujących, do świadczenia swoim życiem o Chrystusie.

W każdej parafii trzeba powołać zespół liturgiczny, którego zadaniem będzie wspólna organizacja liturgii niedzielnej. Należy zadbać, aby przynajmniej jedna Msza niedzielna miała charakter bardziej uroczysty, czyli była celebrowana z pełną asystą liturgiczną, starannie przygotowanymi śpiewami, uroczystą procesją wejścia, użyciem kadzidła, itp. W katedrze oraz bazylikach mniejszych archidiecezji należy przynajmniej raz w miesiącu odprawiać Mszę św. w języku 
łacińskim. Natomiast we wszystkich parafiach uczyć wiernych podstawowych śpiewów gregoriańskich.

Prezbiterzy przewodniczący celebracji liturgicznej otrzymują uprawnienie do podejmowania decyzji o udzielaniu Komunii pod dwiema postaciami. Zaleca się, aby w każdej parafii liczba nadzwyczajnych szafarzy Komunii św. była odpowiednia do potrzeb wspólnoty. Archidiecezjalne Centrum Formacji Pastoralnej zobowiązane jest do opracowania szczegółowego programu formacji tych osób, a także przygotowujących się do przyjęcia posługi lektora i akolity, niebędących alumnami seminarium duchownego i innych członków służby liturgicznej. Ponadto należy podtrzymywać zwyczaj wykonywania posługi ministrantów przez chłopców, młodzieńców i mężczyzn.

Synod nakazuje, oddzielanie nabożeństw eucharystycznych od nieszporów w niedziele i uroczystości. Trzeba zadbać o chrystocentryczny charakter nabożeństw, zwłaszcza odprawianych z monstrancją, w tym również różańcowego. Natomiast w ciągu dnia należy w parafiach organizować grupy osób adorujących Najświętszy Sakrament, stąd też świątynie muszą pozostawać otwarte dla wiernych.

W celu ustalenia pewnego porządku w parafii, szczególnie dla owocnego sprawowania sakramentów, uchwały synodalne stanowią, iż zachowuje się tradycję spowiadania pół godziny przed każdą Mszą św. Ponadto zawierają zachętę, aby wychowywać wiernych do przystępowania do spowiedzi przed rozpoczęciem Eucharystii, a nie w trakcie jej celebrowania. Czyni to zadość zasadzie, według której $\mathrm{w}$ danym momencie sprawuje się w świątyni tylko jeden sakrament, a nie równocześnie kilka obok siebie.

W okresie Adwentu i Wielkiego Postu zaleca się wspólnotową celebrację sakramentu pokuty i pojednania, $\mathrm{z}$ indywidualnym rozgrzeszeniem oraz nabożeństw pokutnych. Taka forma sprawowania sakramentu podczas specjalnego nabożeństwa pokutnego pozwala $\mathrm{z}$ jednej strony lepiej przygotować się penitentom do spowiedzi, $\mathrm{z}$ drugiej zaś wydaje się być niejako mniej nużąca dla spowiedników, którzy przed najważniejszymi świętami, w krótkim czasie, muszą wyspowiadać często dużą liczbę wiernych. 
W wybranej parafii dekanatu lub większego miasta zaleca się dziekanom, aby we współpracy z proboszczami i parafialnymi radami duszpasterskimi, zorganizowali miejsce w którym przez dłuższy okres w ciągu dnia będzie dyżurował spowiednik. Rewolucyjną zmianą w prawie diecezjalnym jest natomiast zniesienie obowiązku poświadczania przez podpis spowiednika, przystąpienia penitenta do spowiedzi. Wymaganie takowe zostaje bowiem $\mathrm{w}$ archidiecezji zniesione.

Należy dbać o to, aby sakrament namaszczenia chorych przyjmowały osoby rzeczywiście chore lub w podeszłym wieku. Wskazane jest udzielanie go przy okazji odwiedzin chorych w domach, pielęgnując zwyczaj odbywania tego w pierwsze soboty miesiąca. Należy unikać zasady periodyczności (przyjmowania raz do roku), kierując się natomiast kryterium stanu zdrowia lub podeszłego wieku.

Zarządza się, aby w Wyższym Śląskim Seminarium Duchownym kontynuować okres propedeutyczny dla alumnów, obejmujący pełny rok formacyjny. W trakcie okresu propedeutycznego, a także późniejszej formacji seminaryjnej, należy wspierać proces budowania relacji interpersonalnych i integracji grupy, poprzez formację duchową, prowadzoną przez ojców duchownych, oraz w razie potrzeby, przy wsparciu psychologów. Zaleca się wprowadzenie w seminarium stażu duszpasterskiego dla alumnów, trwającego jeden semestr. Odbywać się on ma w parafiach archidiecezji katowickiej oraz obejmować alumnów przed Admissio. Celem stażu będzie doświadczenie realiów życia kapłańskiego oraz lepsze przygotowanie praktyczne do pracy duszpasterskiej.

W ramach formacji seminaryjnej alumni drugiego roku kierowani są na obowiązkowy staż pracy w szpitalach lub placówkach „Caritas”. Zaleca się ponadto organizowanie misyjnych staży kleryckich, we współpracy i przy wsparciu osób odpowiedzialnych za krzewienie ducha misyjnego w Kościele lokalnym.

Do zadań Wydziału Duszpasterstwa Rodzin należy przygotowanie różnych kierunków formacji grup wiernych do małżeństwa i rodziny, oraz funkcja weryfikacyjna - w odniesieniu do podmiotów zajmujących się omawianymi kwestiami - ocena kompetencji, 
monitorowanie przy pomocy ankiet, diagnozowanie nowych potrzeb. Ponadto Wydział Duszpasterstwa Rodzin we współpracy z Wydziałem Teologicznym Uniwersytetu Śląskiego powinny opracować programy kształcenia uniwersyteckiego na kierunku nauki o rodzinie, teologicznych studiów podyplomowych oraz programy współpracy w dziedzinie badań naukowych. Te ostatnie znakomicie wpisują się w kierunki rozwoju nauki w Polsce, czyli współpracę jednostek naukowo-badawczych z instytucjami wdrażającymi poźniej te badania w życie. Inne cenne zalecenie dotyczy wypracowania przez wyżej wspomniany wydział kurialny wskazań dla proboszczów, związanych z pracą duszpasterską z rodzinami i osobami dotkniętymi skutkami emigracji zarobkowej.

Zachęca się proboszczów do zorganizowania duszpasterstwa małżeństw i rodzin znajdujących się w sytuacjach wyjątkowych i nieprawidłowych (rodziny rozbite, związki niesakramentalne, konkubinaty). Powinni też podjąć współpracę z podmiotami i organizacjami działającymi na rzecz rodziny, ze szczególnym uwzględnieniem samorządów. Dotyczy to między innymi zadania przygotowania do małżeństwa.

Reasumując, należy zauważyć, iż normy synodalne poruszają wiele istotnych problemów duszpasterskich z zakresu prawa o sakramentach, takich jak przykładowo gruntowniejsze przygotowanie do sakramentów, w tym między innymi emigracja zarobkowa wiernych i związane z tym trudności w zawarciu małżeństwa. Z pewnym rozczarowaniem można stwierdzić, że nie zauważają one pojawiających się coraz częściej na horyzoncie w kraju i diecezji trudnych kwestii, jak np. chrzest dzieci rodziców żyjących w związkach nieformalnych, zawieranie małżeństw z muzułmanami itd., z którymi często nie radzą sobie ani proboszczowie, ani też kuria. Prawdopodobnie nie pojawiły się one w polu zainteresowań synodu, który zajmował się i tak dużą liczbą problemów dotyczących spraw sakramentalnych. Ponadto (co należy uznać za duży atut) II Synod Archidiecezji Katowickiej, w zakresie problematyki omawianej w niniejszej publikacji, można uznać za synod o charakterze duszpastersko-prawnym, a więc 
zawierającym nie tylko ukazanie problemów i kwestii pastoralnych, ale również konkretne ich rozwiązania o charakterze kanonicznym.

\section{The sacraments in the declarations and decrees of II Archdiocesan Synod in Katowice}

In the years 2015-2016 in Katowice took place II Archdiocesan Synod. After its completion declarations and decrees was issued. Some of these concern issues related to the sacraments. Synodal norms raise very important pastoral problems of baptism, confirmation, Eucharist, penance, anointing of the sick, sacrament of order and marriage. Many of decrees concern preparation for the reception sacraments. This publication shows archdiocesan synodal law and interprets it.

SŁOWA KLUCzowe: synod archidiecezjalny; chrzest; bierzmowanie; Eucharystia; pokuta; sakrament namaszczenia chorych; sakrament święceń; małżeństwo; uchwały synodalne; sakramenty

KEY WORDS: archdiocesan synod; baptism; confirmation; Eucharist; penance; anointing of the sick; sacrament of order; marriage; synodal declarations and decrees; sacraments

\section{Nota o Autorze:}

Ks. PROF. ZW. DR HAB. ZBIgNiEW JANCZEWSKI - pracownik naukowo-dydaktyczny na Wydziale Prawa Kanonicznego Uniwersytetu Kardynała Stefana Wyszyńskiego w Warszawie, kierownik Katedry Prawa o Posłudze Uświęcania. 